\title{
Innovatív példa a hallgatók egészségformálására a Semmelweis Egyetem Pető András Karon
}

\author{
An innovative example for raising health awareness among students \\ at the András Pető Faculty of Semmelweis University
}

Szerző:

\author{
Dr. habil. Szilárd Zsuzsanna $\square$ \\ Semmelweis Egyetem Petö András Kar, Budapest
}

Beküldve: 2020. 08.13.

doi: $\quad$ 10.24365/ef.v61i2.506

\begin{abstract}
Összefoglaló:
Bevezetés: Az egészségtelen életmód nagymértékben hozzájárul a magyar lakosság kedvezőtlen egészségi állapotához. A lakosság egészségtudatosságának megerősitése, az egészséges életmódot folytatók számának növelése jelentősen segítené a lakosság egészségi állapotának javulását. Ennek érdekében számos intézkedést vezettek be hazánkban, pl. 2011-ben a népegészségügyi termékadót a népegészségügyileg nem hasznos élelmiszerek visszaszorítása és az egészséges táplálkozás előmozdítása érdekében. A 2012/2013-as tanévtől felmenő rendszerben bevezetésre került a közoktatásban a mindennapos testnevelés. 2011-től pedig a felsőoktatási intézményeknek az alaptevékenységhez igazodóan biztosítania kell egészségfejlesztést is.

Módszertan: A Semmelweis Egyetem Pető András Karon a 2017/2018-as tanévben ötletem alapján szerveztük meg először, majd a következő két tanévben folytattuk az „Év legegészségesebb évfolyama” versenyt. Ez egy olyan egyedülálló kezdeményezés a felsőoktatásban tanuló hallgatók részére, ahol megismerkedhettek az egészségtudatos magatartással, az egészségélményüket megoszthatták egymás között. Kérdőívvel felmértük a hallgatók egészséggel kapcsolatos tudását, szokását, igényeit, az egészségi állapotukat, táplálkozási, pihenési szokásaikat, mozgásszervi panaszaikat, illetve mértük az antropometriai adatokat és motoros képességeik szintjét. Az adatokat az SPSS statisztikai programmal elemeztük.

Eredmények: Az egészséggel kapcsolatos szakmai fórumokon és a programon való részvétellel olyan versenyt szerveztünk az évfolyamok között, ahol mindenki megoszthatta az aznapi egészségélményeit a közösségi médiában. A saját egészségélménnyel a saját évfolyamnak lehetett a pontokat gyüjteni a tanév végéig. A program hatására az első tanév végére a hallgatók több mint egyharmada elkezdett valamilyen új mozgásos tevékenységet. A második tanévben három előadással bővült a program. A tanév végére a hallgatók $77 \%$-a bekapcsolódott a programba. Az év végén felvett elégedettségi kérdőív alapján a válaszadók $20 \%$-a változtatott az eddigi életén és kezdett egészségtudatosan élni.
\end{abstract}

Következtetés: A kezdeményezesünk hatására hallgatóink többsége csatlakozott a programhoz, napi rutin lett az egészségtudatosság, közösen szerveztek programokat. A posztokban egymás ötleteit, tanácsait, egyéni tapasztalatait is megismerhették. Biztatták egymást, és többen ezen posztok hatására kezdtek el egészségtudatosabban élni. Sokan ráébredtek, hogy érdemes tenni az egészségükért.

Kulcsszavak: egészségprogram; mozgás; táplálkozás; kikapcsolódás; közösségi média 


\begin{abstract}
Summary:
Introduction: Unhealthy lifestyle greatly contributes to the unfavourable health status of the Hungarian population. Strengthening the health awareness of the population, the increase of those living a healthy lifestyle could substantially improve the health of the population. Hungary has introduced numerous measures to this end, like the public health product tax in 2011 to reduce the consumption of unhealthy food products and to promote a healthy diet. From 2012/2013 onwards daily physical education was introduced in Hungarian public education. From 2011 higher education institutions also have to provide for health promotion in accordance with their curriculum.
\end{abstract}

Methods: Based on my original idea, SEPAK (Semmelweis University Pető András Faculty) organised "The healthiest class of the year" contest in the 2017/2018 academic year. This is a unique initiative for students in higher education to learn about health-conscious attitudes and to share their health-related experiences with each other. We used a questionnaire to assess the knowledge of the students about their health, habits, needs, health status, nutrition and resting habits, any locomotory complains, anthropometric data and motor skills. We analysed the data using the SPSS statistics application.

Results: We used subjective and objective data to organize health related awareness raising presentations and ran a contest among the different classes studying at the faculty in which every participant shared their daily health-related activities on social media. Each of these social media posts is given points that were collected until the end of the year. Inspired by the program more than $30 \%$ of the students began some sort of regular physical activity by the end of the year. In the course of the second year we organized three major lecturers and $77 \%$ of all students had participated by the end of the school year. Based on a survey conducted at the end, $20 \%$ of participants responded that they had changed their lifestyle and were living a healthier life.

Conclusion: The initiative inspired students to join the program, health-conscious life became a daily routine, participants began to organize programs with each other. The social media posts helped them learn from each other's ideas, advice and experiences. They cheered each other on, many started to live more consciously and began to understand that it was worth doing for their health.

Keywords: health program; exercise; nutrition; recreation; social media

\section{BEVEZETÉS}

Az emberek számára az egyik legfontosabb érték az egészség, az azzal való tudatos foglalkozás (egészségmegőrzés, gyógyítás, helyreállítás), és egyben napjaink egyik legnagyobb kihívása (is) az egészségfejlesztés. ${ }^{1}$ „Az egészséget a sportos életmód, az egészséges táplálkozás, a harmonikus társas kapcsolatok, az életen át kitartott célok és motiváció jelentik." ${ }^{2} \mathrm{Az}$ Egészségügyi Világszervezet (WHO) az Ottawai Kartában így határozta meg az egészségfejlesztést (health promotion): „Az egészségfejlesztés az a folyamat, amely módot ad az embereknek, közösségeknek egészségük fokozott kézbentartására és tökéletesítésére. A teljes fizikai, szellemi és szociális jóllét állapotának elérése érdekében az egyénnek vagy csoportnak képesnek kell lennie arra, hogy megfogalmazza és megvalósítsa vágyait, kielégítse szükségleteit, és környezetével változzék vagy alkalmazkodjon ahhoz. Az egészséget tehát, mint a mindennapi élet erőforrását, nem pedig mint életcélt kell értelmezni. Az egészség pozitív fogalom, amely a társadalmi és egyéni erőforrásokat, valamint a testi képességeket hangsúlyozza. Az egészségfejlesztés tehát nem csupán az egészségügyi ágazat kötelezettsége." ${ }^{3,4}$ (9.o.) Fodor József 
orvos, egyetemi tanár szerint: „Az egészségvédelem nemcsak orvosi, de pedagógiai feladat is: ha többet nevelünk, kevesebbet kell gyógyítani." ${ }^{5(68.0)} \mathrm{A}$ hazai oktatásban az egészségtan tantárgy foglalkozik azon ismeretek, attitűdök, magatartásmódok megismerésével, elsajátításával, melyek szükségesek az egészséges életmód kialakításához és megőrzéséhez.

Az életmód befolyásolja az egyén egészségi állapotát, amely meghatározza az életminőséget és lehetővé teszi az élethosszig tartó egészség megtartását. ${ }^{6}$ Társadalmi szintû tudásátadás szükséges az elérni kívánt egészségügyi változások megvalósulásához. $\mathrm{Az}$ emberek egészségműveltségének szintje és az az egészség jelentős mértékben befolyásolható a tudatos életmóddal, a társadalmi és fizikai körülmények megteremtésével, az egészséges élethez szükséges erőforrások hozzáférhetőségével. ${ }^{7}$

A felsőoktatásban tanuló hallgatók kevesebb, mint egyharmada sportolt (28,8 \%) egy 2016-os felmérés alapján. ${ }^{8} \mathrm{~A}$ hallgatók közel negyede (23\%) éri csak el a WHO által meghatározott heti minimum 150 perces mozgást. ${ }^{7}$ A 2012/2013-as tanévben bevezetésre került felmenő rendszerben a mindennapos testnevelés. A Magyar Diáksport Szövetség a 2014/2015-ös tanévtől kezdődően a magyar köznevelési rendszer kötelező és egységes fittség mérési módszere (NETFIT) alapján a tanulók fittségi eredményeit követi nyomon. ${ }^{9} \mathrm{~A}$ mindennapos testnevelés eredményességét a testneveléshez szükséges teremkapacitás hátráltatja. A 2017/2018-as tanévben kezdték meg felsőoktatási tanulmányaikat azok a hallgatók, akik a középiskolában tanulmányaik során mindennapos testnevelésben részesültek. A felsőoktatási intézményeknek nagy kihívást jelent a sport terén az infrastrukturális helyzet, mivel ez fejlesztésre szorul. ${ }^{10}$

A felsőoktatási intézményeknek is törekedniük kell arra, hogy a hallgatóknak lehetőséget biztosítsanak az egészség javítására, szinten tartására, tehát a WHO által is megfogalmazott „az egyén teljes testi, lelki (szellemi), szociális jóllétét."11 A University of Central Lancashire 1995-ben kezdeményezte az Egészségfejlesztő Egyetemek Programot, amely a WHO „Egészséget mindenkinek” globális programjának alapfelvetéséhez illeszkedett. 2010-ben megalakult az Európai Egészségfejlesztő Egyetemek Hálózata (European Network for Health Promoting
Universities, EuroHPU) is. ${ }^{12}$ A 2011. évi CCIV. törvény a nemzeti felsőoktatásról 11.§ (2) bekezdése szerint „a felsőoktatási intézménynek az alap-tevékenységéhez igazodóan biztosítania kell egészségfejlesztést is, beleértve a rendszeres testmozgás és sporttevékenység megszervezését...."13 (7.0)

Az egészségtudatos magatartás, az egészségfejlesztés az egyetemi polgári kultúrának fontos részévé kell, hogy váljon. A Felsőoktatási Tervezési Testület (FTT), a Nemzeti Egészségfejlesztési Intézet (NEFI) és a Magyar Egyetemi-Főiskolai Sportszövetség (MEFS) ezt céljának tűzte ki. A képzési és kimeneti követelmények átdolgozása, bővítése az egészségfejlesztést, a tudatos egészségmagatartást támogató felsőoktatási környezetet szolgálhatja. ${ }^{11}$ Az Ottawai Charta megállapítása: „Az egészséget az emberek a mindennapi életük körülményei között teremtik és élik meg: ott, ahol tanulnak, dolgoznak, játszanak és szeretnek." ${ }^{\prime 14}$ (4.o) Az Egészségfejlesztési Egyetem Program célja egy egységes egészségés életminőség célú, hallgatóközpontú rendszer létrehozása. ${ }^{15}$

A felsőoktatási intézményeknek célként kellene kitǔzni, - mint ahogy ezt a Semmelweis Egyetem teszi - hogy az egyetem múködésének minden szintjén az egészségtudatosságot képviselje, a rendelkezésére álló eszköztárát bővítse. ${ }^{16}$ 2018-ban a Semmelweis Egyetemen létrehozta a Semmelweis Egészségfejlesztési Központ, melynek célja a szemléletformálás, az egészségmegőrzés korszerű szervezeti kereteinek megteremtése. Első intézkedésnek a 2019/2020-as tanévtől az egyetem minden karán és minden évfolyamán bevezették a testnevelés tantárgyat. ${ }^{16}$

Jelen közlemény célja, hogy egy innovatív példát mutasson be a közösségben történő egészséggel kapcsolatos szemléletformálás témában. Az „Év legegészségesebb évfolyama" verseny a Semmelweis Egyetem Pető András Karon 2017/2018-as tanévben kezdődött és azóta is múködik.

\section{MÓDSZERTAN}

A 2017/2018-as tanévben, a Semmelweis Egyetem Pető András Karának nappali tagozatos hallgatói számára (N=294) hirdettük meg először kezdeményezésemre $A z$ „Év legegészségesebb évfolyama" 
versenyt, majd a 2018/2019-es tanévben ( $N=304)$ megismételtük azt. A verseny célja az volt, hogy minél több hallgató kezdjen el egészségtudatosabban élni. Az egészség összetevői közül nem csak egy területtel foglalkoztunk, hanem több oldalról próbáltuk az egészségtudatosságot formálni. Olyan programokat igyekeztünk kitalálni, ami közös élményt ad. Motivációnak pontgyűjtési lehetőségeket ajánlottunk fel, a pontverseny állását a közösségi hálón a versenyre létrehozott zárt csoporthoz történő csatlakozás után követhették a hallgatók, $s$ itt oszthatták meg saját élményeiket, képeiket is. A programokon, valamint a közösségi hálón való részvétellel a hallgatók pontokat gyűjthettek az évfolyamuknak. A részvételnek köszönhetően a közösségben az egészségtudatos életmód egyre népszerübbé vált. A hallgatók megismerhették társaik egészséggel kapcsolatos jó szokásait, és ezzel motiválták egymást, ezen kívül a győztes évfolyam elnyerte a Vándorserleget.

A verseny időtartama egy tanévre szólt, a versenyen minden hallgató részt vehetett, a meghirdetett programokhoz bármikor csatlakozhattak a tanév során. A jelentkezésnek nem volt feltétele az egész tanéves, minden programon való részvétel. A verseny során különböző előadásokat és szabadidős tevékenységeket hirdettünk meg (az esemény idejéről, helyszínéről, a részvétel feltételeiről minden hallgatót előzetesen tájékoztattunk), az ezeken történő részvételt eseményenként dokumentáltuk. Ezen kívül a napi egyénileg szervezett saját egészségélmény is beleszámított a versenybe. A hallgatók az általunk meghirdetett programokon történő részvételért, a saját aktivitásukkal kapcsolatos élményeik közösségi hálón történő megosztásáért egy előre meghatározott pontrendszer alapján pontot kaphattak. Minden tevékenységért 5-5 pont járt, ha videóval küldték, plusz pontot ért. Voltak események, amik további plusz pontokat értek. Minden feltöltést a teljesítés naplóban vezettem, évfolyamok bontásában. A hallgatók által a közösségi hálóra feltöltött tevékenységeket nem minősítettük vagy rangsoroltuk, csak feltöltést könyveltük el. A hallgatókat a pontverseny állásáról heti rendszerességgel tájékoztattuk.

A tanév elején egyrészt felmértük hallgatóink egészséggel kapcsolatos gondolatait, érzéseit és a szubjektív egészségérzetüket, másrészt félévente 4-5 aktív programot ajánlottunk fel számukra.
A szubjektív adatok begyűjtéséhez egy 35 nyílt és zárt kérdésekből álló saját kérdőivet használtunk, amit év elején töltöttek ki a hallgatók. Felmértük a hallgatók szubjektív egészségi állapotát (8 kérdés), az egészség fontosságról ( 8 kérdés) alkotott véleményüket, egészségszokásaikat ( 8 kérdés), táplálkozási szokásaikat (5 kérdés), mozgásszervi panaszaikat (6 kérdés). A kérdőív kérdései az egészségi állapotukra, az egészségérzésükre, az egészségtudatosságra, sportolási, étkezési, kikapcsolódási szokásaikra kérdeztek rá. Ezen kívül minden esetben azonos feltételek mellett - az aktuális fizikai fittségüket mini Hungarofit (azért ezt a mérést választottuk, mert tíz évvel ezelőtt ezzel mértük az akkori hallgatóinkat és egy másik tanulmányban fel tudtuk használni az adatokat), és antropometriai adataikat egy BF511 test összetétel elemző monitorral is mértük. ${ }^{17,18} \mathrm{~A}$ mért adatokat rögzítettük és SPSS 25 statisztikai programmal elemeztük. Minden tanév végén elégedettségi kérdőívet tölthettek ki a hallgatók, mellyel visszajelzéseket kaphattunk a programról.

Kíváncsiak voltunk, hogy a hallgatók tisztában vannak-e egészségükkel, képességeikkel, hiányosságaikkal, illetve látják-e hogyan lehetne egészségesen élni. Választ vártunk arra, hogy milyen összefüggés mutatható ki a saját egészséggel kapcsolatos érzések, vélemények, panaszok és a fizikai teljesítőképességük között. Az eredményekről a közösségi hálón és plakátokon folyamatosan tájékoztattuk a hallgatókat.

\section{EREDMÉNYEK}

$A z$ „Év legegészségesebb évfolyama” versenyen, az általunk szervezett, meghirdetett programokon való részvétel nem volt kötelező, mindenki bármelyik programhoz bármikor csatlakozhatott. A programokat és a részvételi arányt az 1 . ábra mutatja.

Az egészséges életmóddal kapcsolatos kérdőívet 2017-ben az első-, másod-, harmadéves és végzős hallgatók, 2018-ban csupán az elsőéves hallgatók töltötték ki, összesen 298 fő. A kitöltők 98\%-a nő, átlagéletkoruk 22,4 év.

A kérdőív adatainak elemzéséből kiderül, hogy az egészségtudatosságot véleményük szerint döntően két dolog befolyásolja, ezek a táplálkozás és a 
mozgás. „Az egészségem általában” kérdésre a hallgatók 14\%-a válaszolta, hogy egészsége nagyon jó, 60\%-uk elégedettnek, 22\%-uk kielégítőnek vélte egészségét. A „Tehetek-e az egészségemért” kérdésre a hallgatók 47\%-a választotta azt, hogy „Nagyon sokat tehet saját egészségéért”, 42\%-uk pedig azt, hogy „Keveset tehetek az egészségemért".
A „Mennyire vagy elégedett a fizikai állapotoddal?” kérdésre a válasz a következőképpen oszlott meg: 40\%-uk mérsékelten elégedett, 47\%-uk nagyjából és 6\%-uk nagyon elégedett. A megkérdezettek majdnem fele (49\%) a „Heti rendszerességgel végzel sportmozgást?" kérdésre igennel válaszolt.

1. ábra: A Semmelweis Egyetem Pető András Kar 2017/2018-as és 2018/2019-es tanévben az "Év legegészségesebb évfolyama” verseny programjai és a programokon való hallgatói részvételi arány
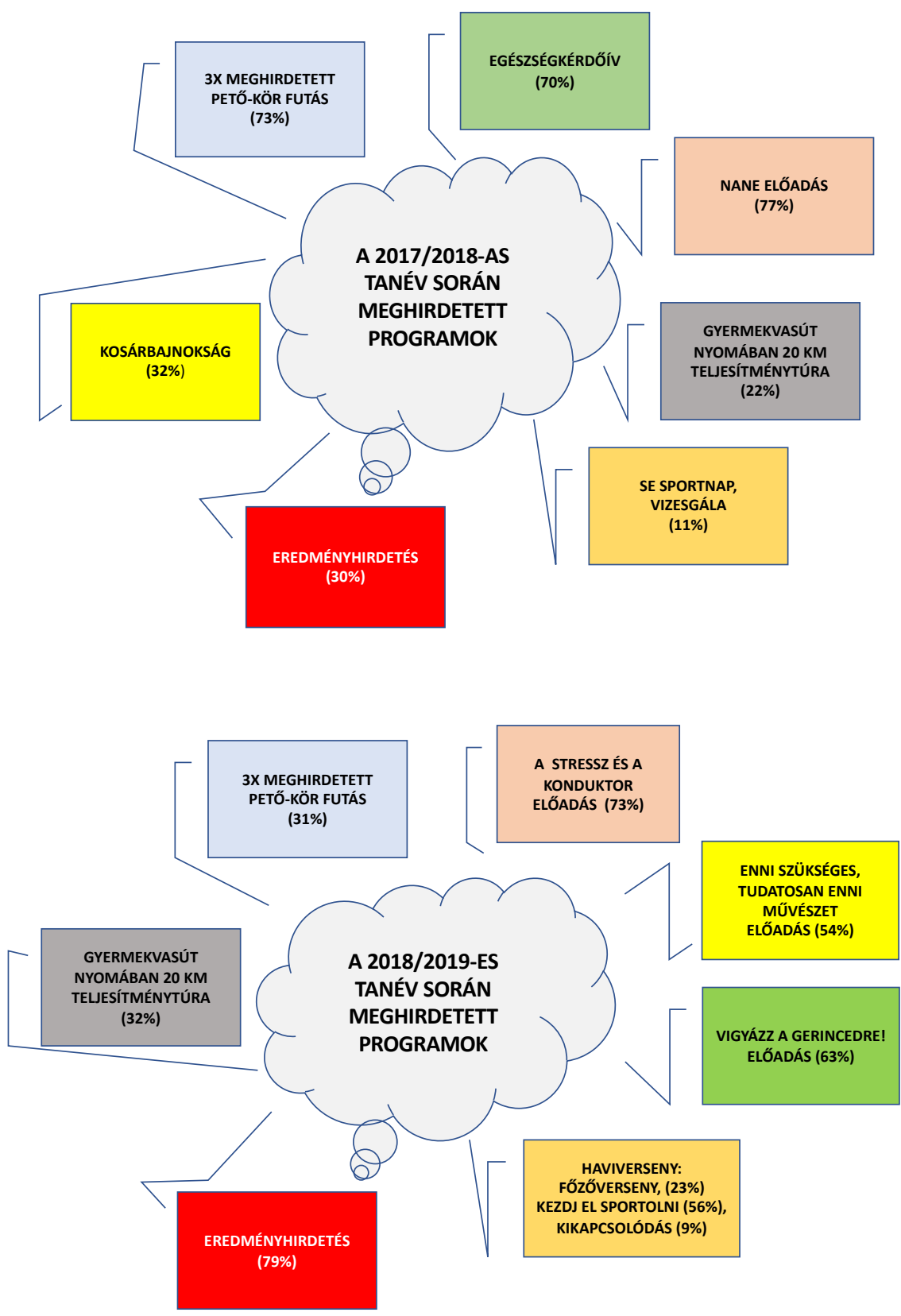

Forrás: Saját szerkesztés 
A „Mi az oka, ha nem sportolsz?” kérdésre voltak, akik időhiányra (12\%) panaszkodtak, de volt, aki bevallotta, hogy lustaságból (12\%) nem sportol, vagy azért, mert sokba kerül. A „Milyen gyakran sportolnál?" kérdésre adott válaszok alapján, ha tehetnék, a heti 2-3 alkalmat választanák. A „Milyen sportolást választanál, ha lenne rá lehetőséged?" kérdésre az alakformáló fitneszedzéseket nevezték meg a hallgatók.

A hallgatók 45\%-ának van mozgásszervi panasza, amint ez kiderült a „Van-e jelenleg mozgásszervi panaszod?" kérdésre adott válaszokból. Ezek leggyakrabban hátfájás, derék és térdfájás. Néhányan (12\%) ízületi problémát említettek. Azoknak, akinek van mozgásszervi panasza, negyedét a hétköznapokban is zavarja. A "Hogyan enyhíted panaszaidat?" kérdésre adott válaszok alapján a fájdalmak kezelésére döntően krémeket, masszírozást választanak leggyakrabban, orvoshoz mindössze 12\%-uk fordul.
„A táplálkozási szokásokra jellemző” kérdésre adott válasz szerint a hallgatók harmada egészségesnek tartja táplálkozási szokásait. A „Van-e ételallergiád?" kérdés feltárta, hogy a válaszadók 27\%-ának ételallergiája van.

A fizikai állapotfelmérés eredménye azt mutatja, hogy hallgatóink szubjektív fittségérzetüket jobbra értékelik. (A Mini Hungarofit eredmények egy korábbi közleményben részletesebben is elérhetők. ${ }^{18}$ ) A hallgatók fizikai felmérésének eredményei alapján első évben érik csak el az egészséges létezéshez, a testi, lelki, biológiai, fiziológiai egyensúlyhoz és a maradéktalan munkavégzéshez szükséges „kell” értéket (közepes). A felsőbb évesek ennél rosszabb fizikai állapotban vannak. Az antropometriai mérések alapján a testtömeg index (TTI) legkisebb értéke 16,5, a legmagasabb 40,9, az átlag és szórás 22,3 (4,6) volt. Az 1. táblázat a Mini Hungarofit által mért fizikai állapotot, illetve a kérdőívben a fizikai állapotra vonatkozó kérdések eredményeit mutatja évfolyam részvételi bontásban.

1. táblázat: A saját egészséggel, fizikai állapottal kapcsolatos eredmények, évfolyambontásban a részvételi arány a kérdőív és a fizikai állapotmérése alapján ( $N=298)$

\begin{tabular}{|c|c|c|c|c|}
\hline & $\begin{array}{l}1 . \\
\text { évfolyam } \\
(85 \%)\end{array}$ & $\begin{array}{l}2 . \\
\text { évfolyam } \\
(73 \%)\end{array}$ & $\begin{array}{l}3 . \\
\text { évfolyam } \\
(70 \%)\end{array}$ & $\begin{array}{l}4 . \\
\text { évfolyam } \\
(65 \%)\end{array}$ \\
\hline Fizikai állapot & közepes & kifogásolható & gyenge & igen gyenge \\
\hline BMI (szórás) & $21,7(3,6)$ & $22,63(6,2)$ & $21,8(3,8)$ & $21,8(2,9)$ \\
\hline $\begin{array}{l}\text { Heti rendszerességgel végzel sportmozgást } \\
\text { szabadidődben? (\%) igen - nem }\end{array}$ & 54 & 49 & 50 & 58 \\
\hline $\begin{array}{l}\text { Mennyire vagy elégedett a fizikai állapotod- } \\
\text { dal? (\%) 1: Egyáltalán, 2: Nem, 3: Mérsékelten, } \\
\text { 4: Nagyjából, 5: Nagyon }\end{array}$ & 2,53 & 1,79 & 1,78 & 2,75 \\
\hline $\begin{array}{l}\text { Van-e jelenleg mozgásszervi panaszod? (\%) } \\
\text { Igen- Nem }\end{array}$ & 35 & 44 & 43 & 57 \\
\hline $\begin{array}{l}\text { Van-e valami ételallergiád?(\%) } \\
\text { Igen- Nem }\end{array}$ & 25 & 19 & 21 & 25 \\
\hline
\end{tabular}

Forrás: saját forrás

A hallgatóinknak a 2017/2018-as tanév második félévében meghirdettünk egy előadást az erőszakmentes kommunikációval kapcsolatban, ezen a hallgatók 77\%-a vett részt. A félév során három alkalommal hirdettük meg a Pető kört. Ez egy 1400 m hosszú táv, melyet futva, sétálva, bármilyen eszközzel lehetett teljesíteni. Hallgatóink 78\%-a jött el erre a programra. A kosárbajnokságot hat csapattal tudtuk megrendezni. Az évfolyamokból erre az eseményre a hallgatók 10\%-a jött el szurkolni. 
Ebben a félévben a $20 \mathrm{~km}$-es teljesítménytúrán a hallgatók $22 \%$-a részt vett. Az első tanév végén a 2. évfolyam nyerte el a Vándorserleget.

Hallgatóink az első tanév végén (26\%), egy 34 nyílt kérdésből álló elégedettségi kérdőívet tölthettek ki anonim módon. A válaszokból az derült ki, hogy a hallgatóknak tetszett (89\%) ez az új kezdeményezés. Többen (78\%) jelezték, hogy nem gondolták volna, hogy mennyi apró cselekedet van naponta, ami egészséges, és ahogy olvasták mások posztjait, többen megpróbáltak egészségesen étkezni, mozogni, kikapcsolódni. A pontversenyt eleinte (35\%) nem tartották igazságosnak, mert pl. az almaevés is pontot ért, ha megosztották, és sajnos néhányan viccet csináltak ebből. Majd a pontosabb tájékoztatás után megértették, hogy az almaevés is lehet az egészségtudatosság kezdete, ha nem is ebből áll csak a tudatosság. Az első tanévben fóleg a sport, a mozgás volt előtérben, és kérések (91\%) fogalmazódtak meg a táplálkozással, stressz kezeléssel kapcsolatban előadások szervezésére. A válaszokból kiderült, hogy azok, akik nem vettek részt (25\%) a programokon, nem értesültek a lehetőségről előzetesen. Ha újra szerveznénk ezt a programot, a válaszadók 78\%-a jelentkezne.

2018/2019-es tanévben az első félévben három előadást szerveztünk. A tudatos táplálkozás előadáson a hallgatók 54\%-a, a stresszkezelésen $73 \%$-a, a gerincprevenció előadáson pedig a $63 \%$-a részt vett. A Pető kört is meghirdettük három alkalommal, ami 24-22-11\%-os részvételt eredményezett. A tavaszi félévben egy-egy hónap csak a főzésről, a mozgásról és a kikapcsolódásról szólt. Az ezzel kapcsolatos posztokért kaphattak plusz pontokat. A program meghirdetésétől folyamatosan posztolták hallgatóink az aznapi egészségélményüket. Decemberre a hallgatók 73\%-a csatlakozott a programhoz. A tavaszi félévben a $20 \mathrm{~km}$-es teljesítménytúrán 32\%-uk vett részt, a havi fözőversenyen 23\%-uk, a havi sport-mozgás-versenyen 56\%-uk, továbbá a kikapcsolódás- és stresszkezelésversenybe 9\%-uk kapcsolódott be. A saját egészségélményüket voltak, akik napi, heti szinten rendszeresen (18 fő) posztolták, de mi annak is örültünk, ha valakinek csak ritkán, de eszébe jutott a saját aznapi egészségéről posztolni valamit. Az utolsó" új" résztvevő márciusban csatlakozott a programhoz.

A posztokból kiderült, hogy a mások által megosztott tevékenységek motiválók tudnak lenni. Többen saját bevallásuk szerint elkezdtek sportolni, azóta jobban odafigyelnek a táplálkozásra, és több folyadékot isznak naponta. Alakultak csoportok, akik közösen járnak el sportolni (jóga, falmászás). Létrejött egy futó csapat, akik 2019-ben az Ultra Balatonon is elindultak, és 22 óra alatt körbe futották a tavat. A közösségi hálón a versenyre létrehozott zárt csoportban megosztják edzéseken, versenyeken való részvételeiket. Többen megosztották, milyen edzésekre járnak, milyen versenyeken indultak, illetve azokon milyen eredményeket érnek el. A 2018/2019-es tanévben a 3. évfolyam nyerte el a Vándorserleget. Ebben az évben külön díjaztuk a legaktívabb hallgatókat és oktatókat is.

A második tanév végén is elégedettségi kérdőívet tölthettek ki önkéntes alapon a hallgatók (41\%), azért, hogy még több visszajelzést kapjunk a programról. Ennek a tanévnek a programjai (táplálkozási, stresszkezelési, gerincprevenció előadások, sportprogramok) nagyon tetszettek a hallgatóknak. Úgy érezték, a színvonal még jobb lett az előző évhez képest. Ezt a megnövekedett részvételi arány is alátámasztja. A válaszadók többsége követte az eseményeket a közösségi hálón, tetszett nekik a Vándorserleg elnyerésének pontgyưjtéssel történő lehetősége és a legaktívabbak különdíjazása is. Véleményük szerint az online tevékenység és pontgyűjtés hozzájárult az eseménysorozat sikerességéhez. Egyharmaduk azt jelezte, hogy változott az egészséghez való hozzáállása. Megtudtuk néhányukról, hogy bár ők saját élményüket nem posztolták, és mások élményeit sem like-olták, de „passzívan" mindig figyelték az eseményeket. A jövőre nézve kaptunk javaslatokat, hogy legyen több sportprogram, verseny meghirdetve; még pontosabb legyen a tájékoztatás a közösségi hálón egy esemény létrehozásával; más egyetemekkel is versenyezhessenek.

\section{KÖVETKEZTETÉS}

Gyakran a mentális kimerültség, a kevés vagy hiányzó szabadidő és a munkavégzés következménye a fizikai rosszullét, amely az életminőséget javító egészségtudatos gondolkodással megelőzhető lehetne. A segítő szakmát, mint a konduktor szakmát tanulni vágyók már a képzés alatt is eltérő típusú (fizikai, lelki megterhelés) kihívásokkal 
találkoznak, mint más szakmát tanuló kortársaik. Hallgatóink minden félévben az elméleti képzés mellett folyamatos szakmai gyakorlaton vesznek részt. A gyakorlatok során fekvő, ülő vagy álló helyzetben lévő diszfunkciós mozgássérültekkel találkoznak és sokszor fiziológiásan nem helyes testhelyzetekben kell foglalkozni velük. Ennek hatására már a tanulmányaik alatt megjelenhetnek, és sokaknál sajnos megjelennek mozgásszervi panaszok. A tudatos, edző, szakember által irányított preventív jellegú mozgás ajánlott lenne számukra. Tudatosítani a hallgatóknak, hogy a törzsizmok tudatos és szakszerű erősítése és a konduktori munka során előforduló testhelyzetek helyes kivitelezése a mozgásszervi panaszok kialakulását megelőzheti.

Az "Év legegészségesebb évfolyama" programmal hozzájárulhatunk az általános egészségtudatosság növelésén túl a szakmaspecifikus egészségneveléshez is, amellyel a főiskolai évek alatt megakadályozhatjuk az életminőséget rontó tényezők (mozgásszervi panaszok, hangulatingadozás, egészségtelen táplálkozás, rossz életvezetés) kialakulását. A programban egészséggel kapcsolatos szemléletformálás történik, a hallgatók elsajátíthatnak olyan egészségmegőrző stratégiákat, melyek alkalmazásával megakadályozhatják, késleltethetik, vagy csökkenthetik saját egészségkockázatuk.

A hazai felsőoktatásban egyedülálló, de a nemzetközi szinten is innovatív programot azért hoztuk létre, mert szükségesnek látjuk a hallgatók egészségének formálását. Az egészség óriási érték, mégis erről hallgatóink kevés tudással rendelkeznek, nincsenek tisztában azzal, hogy mit kell tenni, hogy ez hosszútávon fenntartható legyen. A hallgatók az általános iskolában és a középiskolában találkozhattak az egészségneveléssel, mégis hiányos tudással rendelkeznek, ha meg kell fogalmazni, mi is az egészség. Az "Év legegészségesebb évfolyama” versennyel egy olyan szemléletformáló programot alakítottunk ki, melyben tudatos irányítással hívjuk fel a figyelmet az egészségtudatosságra. Célunk, hogy a diploma megszerzésével az egészséggel kapcsolatos tudásaik bővüljenek is. A program alatt azt tapasztaltuk, hogy hallgatóink nem is tudják, hogy az adott tevékenység egészséges. Sokszor a posztokból, azok visszajelzéséből vették észre, hogy másoknak milyen ötleteket adtak. Felhívták mások figyelmét azokra az aprónak tűnő mindennapi tevékenységekre, amit sokszor ők teljesen természetesnek gondoltak (étkezés, sport, mozgás, szabadidő, szabadidős tevékenységek), és ezzel ösztönöztek másokat azok kipróbálására.

A mindennapos testnevelésből érkező hallgatóknak szüksége van a rendszeres, akár napi szintű testnevelésre az egyetemi évek alatt is. Az órarendben a képzés alatt mostanáig csak 2-4 szemeszterben jelent meg a testnevelés. A Semmelweis Egyetem a 2019/2020-as tanévtől minden szemeszterben kötelezővé teszi a testnevelést. Hallgatóink objektív és szubjektív véleménye az egészséggel kapcsolatban jó támpont arra, hogy kitaláljuk milyen programokra, tudásra van szükségük, hogy az egészségüket formálhassuk. Az általunk kezdeményezett program jól mutatja, hogy apró lépések milyen eredményesek tudnak lenni. Hallgatóinkat megkérdeztük a programról az első és a második év végén is. Válaszaikból az derült ki, hogy többekben elindult egy folyamat, amely reményeink szerint egy egészségesebb ifjúságot eredményezhet. Hallgatóink kedvelik ezt a versenyt. Szívesen csatlakoztak az általunk kezdeményezett programokhoz, szeretik, hogy megoszthatják élményeiket, illetve motiváló számukra, hogy mások tapasztalataival gazdagodnak és az ötleteket ők is alkalmazhatják. Ezzel egyre többet tesznek a saját egészségükért. $A$ verseny célja ez volt!

A 2019/2020-as tanévben is folytattuk tovább ezt a programot és reméljük a következő tanévben is fogjuk úgy, hogy bevonjuk a többi kart vagy akár más egyetemeket is. Az egészség kínálatát bővítjük, hogy ne csak a sport és a táplálkozás képezze az egészségről a hallgatók gondolkodását, ezért még több lehetőséget ajánlunk hallgatóinknak ezek megismerésére. Hosszútávon célunk, hogy az oktatásban, a képzési struktúrában is megjelenjenek az egészséggel kapcsolatos tananyagok. Ez még inkább hozzá segítené a hallgatókat a preventív szemlélet és gondolkodás kialakulásához. 


\section{HIVATKOZÁSOK}

\footnotetext{
${ }^{1}$ Kontor E, Szakály Z, Soós M, et al. Egészségtudatos magatartás a 14-25 év közötti fiatalok körében. Hitelesség és értékorientációs a marketingben. XXII. Konferencia Tanulmánykötet. Debrecen. 2016. 640-649.

https://dea.lib.unideb.hu/dea/bitstream/handle/2437/238406/FILE UP 5 EMOK2016-KESZZSMKM-2.pdf?sequence=1\&isAllowed=y (Elérve: 2020.04.06.)

${ }^{2}$ Egészségügyi hozzáférés Konferencia és Egészségfejlesztési Szakmai Fórum 2019. 05.11. EOK. Dr. Kellermayer Miklós előadása. http://semmelweis.hu/hirek/events/egeszsegugyi-hozzaferes-konferencia-es-egeszsegfejlesztes-szakmaiforum/(Elérve: 2020.04.06.)

${ }^{3}$ The Ottawa Charter Health Promotion www.who.int/healthpromotion/conferences/previous/ottawa/en/ (Elérve: 2020. 04. 06.)

${ }^{4}$ Az egészségfejlesztés alapelvei. Az egészségfejlesztés alapvető nemzetközi dokumentumai

http://regi.oefi.hu/modszertan1.pdf (Elérve: 2020.04.20.)

${ }^{5}$ Éger I. A közoktatás szerepe az egészségfejlesztésben. Doktori értekezés. NYME, Sopron 2005. 68..0. http://doktori.nyme.hu/224/1/de_2897.pdf (Elérve: 2020.04.06.)

${ }^{6}$ Ábrahám J. Rekreációs kultúra a fogyasztói társadalomban 2016. Doktori értekezés. Testnevelés Egyetem Sporttudományok Doktori Iskola. 33-47. o. http://real-phd.mtak.hu/465/19/\%C3\%A1brah\%C3\%A1mj\%C3\%BAlia.d.pdf (Elérve: 2020.04.06.)

${ }^{7}$ Mayer K, Boncsér A. Egészségtudatos magatartás szerepe a 18-25 évesek körében. (kézirat) Miskolci Egyetem Egészségügyi Kar Egészségügyi szervező alapszak Egészségturizmus szervező szakirány. 2017. 39. 0. http://midra.uni-miskolc.hu/document/27935/23576.pdf (Elérve: 2020.04.06.)

${ }^{8}$ Czippán K, Drahos P, Gilly Gy, et al. Egészségfejlesztő Egyetem. Alapelvek, célok, koncepciók. Nemzeti Egészségfejlesztési Intézet. 2015. TÁMOP-6.1.1-12/1-2013-0001. Széchényi 2020. 60.0. https://www.academia.edu/33573833/Egeszsegfejleszto egyetem.pdf (Elérve: 2020.04.09.)

${ }^{9}$ Netfit kézikönyv. A Nemzeti Egységes Tanulói Fittségi Teszt. MDSZ. Új Széchenyi terv. 2014. 56-58.0.

${ }^{10}$ Dulcz A. Mindenki sportja az egészséges sport alapja. 17. Edukáció kiállítás, sportolási szokások. 2017. MEFSZ.

${ }^{11}$ Az egészségfejlesztés alapelvei - Az egészségfejlesztés alapvető nemzetközi dokumentumai. Kishegyi J. és Makara P. (szerk) OEFI, Budapest. 2004. ISBN 963865953 http://regi.oefi.hu/alapelvek.pdf (Elérve: 2020.04.06.)

12 Tsouros AD, Dowding G, Thompson J, et al. Health Promoting Universities: Concept, Experience and Framework for Action. WHO. 1998. ISBN 9289012854 http://www.euro.who.int/_data/assets/pdf_file/0012/101640/E60163.pdf (Elérve: 2020.04.06.)

${ }^{132011 . e ́ v i ~ C C I V . ~ t o ̈ r v e ́ n y ~ a ~ n e m z e t i ~ f e l s o ̋ o k t a t a ́ s r o ́ l . ~ 7 . o . ~ h t t p s: / / n e t . j o g t a r . h u / g e t p d f ? d o c i d=a 1100204 . t v \& t a r g e t-~}$ date=\&printTitle=2011.+\%C3\%A9vi+CCIV.+t\%C3\%B6rv\%C3\%A9ny

${ }^{14}$ Health for All. WHO 9th Global Conference on Health Promotion, Shanghai. 21-24 November 2016. 4.0. https://www.who.int/healthpromotion/conferences/9gchp/shanghai-conference-report/en/ https://www.elte.hu/dstore/document/1935/ELTE Eg\%C3\%A9szs\%C3\%A9gfejleszt\%C3\%A9si strat\%C3\%A9gia.pdf (Elérve: 2020.04.06.)

${ }^{15}$ „Egészségfejlesztő Egyetem Alapelvek, Célok, Koncepciók” a TÁMOP-6.1.1-12/1-2013-0001 „Egészségfejlesztési szakmai hálózat létrehozása” kiemelt projekt, felsőoktatási alprojekt keretében. Nemzeti Egészségfejlesztési Intézet. 2015. https://www.academia.edu/33573833/Egeszsegfejleszto egyetem.pdf (Elérve: 2020.04.06.)

${ }^{16}$ Semmelweis Egészségfejlesztési Központ megvalósítási koncepció. Semmelweis Egyetem. 2018 40.p. https://docplayer.hu/111972105-Semmelweis-egeszsegfejlesztesi-kozpont.html (Elérve: 2020.04.06.) ${ }^{17}$ Fehérné Mérey I. Se többet, se kevesebbet - Mérd magad: Hungarofit (Útmutató) Útmutató Kiadó. Győr. 1999. 133-148. o. ISBN 963-9001-42-2

${ }^{18}$ Sáringerné Szilárd Zs. A konduktorhallgatók fizikai állapota tíz év távlatában. Magyar Sporttudományi Szemle 2019;20(1)56-62. https://mstt.hu/wp-content/uploads/2019/10/MSTT-Szemle-2019-1-honlapra.pdf (Elérve: 2020.04.06.)
} 